\title{
IAMJ
}

INTERNATIONAL

AYURVEDIC

MEDICAL JOURNAL

Research Article

ISSN: 2320-5091

Impact Factor: 6.719

\section{AGNIKARMA USING HONEY IN TENNIS ELBOW}

\author{
Sreelatha K. ${ }^{1}$, George M. J., ${ }^{2}$ Rejani H. ${ }^{3}$ \\ ${ }^{1}$ Third Year P.G. Scholar, Dept. of Shalyatantra, V.P.S.V Ayurveda College, Kottakkal Kerala, India \\ ${ }^{2}$ Professor and H.O.D., Dept. of Shalyatantra, V.P.S.V Ayurveda College, Kottakkal, Kerala, India \\ ${ }^{3}$ Professor, Dept. of Shalyatantra, V.P.S.V Ayurveda College, Kottakkal, Kerala, India
}

Corresponding Author: srilata.hari@gmail.com

\section{https://doi.org/10.46607/iamj0309112021}

(Published Online: November 2021)

Open Access

(C) International Ayurvedic Medical Journal, India

Article Received: 06/10//2021 - Peer Reviewed: 27/10/2021 - Accepted for Publication: 29/10/2021

Check for updates

\begin{abstract}
Tennis elbow is a condition in which there is pain on the lateral epicondyle. It is a type of repetitive strain injury due to overexertion of the common extensor tendon (snayu), micro-traumas, or its failed healing. Tennis elbow may be correlated with snāyugata vāta in kūrpara sandhi (elbow) which has symptoms of pain, stiffness and restriction of movements. Ácārya Suśruta has mentioned snigdha agnikarma (thermal cautery) in the management of snayugata vata. 16 participants satisfying the diagnostic, inclusion and exclusion criteria were selected for the study. Agnikarma using honey (madhu) was done on the $1^{\text {st }}$ and $8^{\text {th }}$ days. Clinical assessments were done on the $1^{\text {st }}, 8^{\text {th }}$, $15^{\text {th }}, 22 \mathrm{nd}, 29^{\text {th }}$ days. On statistical analysis, it was found that agnikarma using madhu shows $68.22 \%$ of effect in the management of tennis elbow.
\end{abstract}

Keywords: Tennis elbow, agnikarma, honey

\section{INTRODUCTION}

Tennis elbow is a condition in which there is pain on the lateral epicondyle. ${ }^{1}$ Clinically it is also called lateral epicondylitis or epicondylalgia or tendinopathy ${ }^{2}$ or tendinosis ${ }^{3}$ It is a type of repetitive strain injury due to overexertion of the common extensor tendon (snayu), micro-traumas, or its failed healing. ${ }^{3}$ The pathology behind the tennis elbow remains unknown but it seems to be the sum of tendon defect, change in pain perception, and motor impairment. ${ }^{4}$ This may be also due to a degenerative change at the origin of the extensor carpi radialis 
brevis muscle. ${ }^{5}$ Usually the dominant hand is the more affected one. ${ }^{6}$

Pain becomes severe on the extension of arm and wrist, while gripping and twisting movements of wrist and forearm. The disease is usually confirmed by its features like radiating pain from lateral epicondyle to the forearm and wrist, pain on resisted dorsiflexion of the wrist, tenderness on lateral epicondyle, weakness of forearm, weakened grip strength and morning stiffness. The prevalence of tennis elbow in the general population is about $1-3 \%$ and equally affects both men and women of age group 34-54 years. ${ }^{7}$ The treatments followed nowadays like pharmacological interventions, steroid injections and surgery have their limitations. ${ }^{8}$ So in these circumstances it is relevant to find out management in Ayurveda.

Tennis elbow may be correlated with snāyugata vāta in kürpara sandhi (elbow) ${ }^{9}$ which has symptoms of pain, stiffness and restriction of movements. Ācärya Suśruta has mentioned treatments such as snehana (unction) upanāha (variety of poultice), agnikarma (thermal cautery), bandana (bandaging), and unmardana (strapping) for snayugata vāta. ${ }^{10}$ Agnikarma is mentioned as supreme among all the para surgical procedures. Agni karma is indicated in vatakaphaja diseases, also in atyugraruja (severe pain) of skin, muscles, veins, tendons, joints etc. ${ }^{11}$ Agni possess uşna, tīkșna, sukșma, āśukāriguña and has vattahara and kaphahara properties. The things used for cauterization in snāyugata vāta are snigdha dravya such as madhu (honey), guda (jaggery), taila (oil) and vasa (fat) ${ }^{11}$ as they have deep heat penetration capacity with a greater latent period. ${ }^{12}$ As an outcome of previous studies, agnikarma using madhu is found to be effective in snāyugata vikāra. ${ }^{13}$ Methodology

The study setting was Shalyatantra OPD of VPSV Ayurveda College, Kottakkal. 16 participants satisfying the diagnostic, inclusion and exclusion criteria were selected for the study.

\section{a) Diagnostic Criteria}

Positive Cozen's test, positive Mill's manoeuvre, tenderness at the lateral epicondyle, reduced grip strength

\section{b) Inclusion Criteria}

Tenderness on palpation of the lateral epicondyle, pain during resisted wrist extension at the area of the lateral epicondyle, pain during passive flexion of the wrist along with pronation of forearm at the lateral epicondyle, age group 21- $60 \mathrm{yrs}$. irrespective of gender, unilateral tennis elbow irrespective of side, patients in whom Agnikarma is indicated as per classics.

\section{b) Exclusion Criteria}

Known cases of uncontrolled DM, uncontrolled HTN, Rheumatoid arthritis, Gouty arthritis, TB, pregnancy, known cases having malignant tumours, senile osteoporosis in and around the elbow joint, patients with a history of fractures of lateral epicondyle Detailed history with aggravating and relieving factors was taken in each case. The participants were treated with agnikarma using madhu on the $1^{\text {st }}$ day and $8^{\text {th }}$ day. Assessments were done on the $1^{\text {st }}, 8^{\text {th }}, 15^{\text {th }}, 22^{\text {nd }}$, and $29^{\text {th }}$ days. For patients with a history of trauma to the elbow joint, an X-ray of the elbow was taken to rule out any injuries to the bone. Blood Routine Examination, Clotting Time, Bleeding Time, Erythrocyte Sedimentation Rate, Random Blood Sugar, RA factor, Serum uric acid were also done to rule out other pathologies.

Follow up was done for 14 days. Cozen's test, Mill's manoeuvre, tenderness on lateral epicondyle, range of active flexion and extension of the wrist and the grip strength were assessed. The statistical analysis of the results was done.

\section{Intervention}

\section{Agnikarma Using Madhu}

Materials required were sterile cotton, madhu (honey), gas stove, borosil pipette, pyrometer, ghrta (ghee). The elbow and surrounding area were cleaned with an antiseptic solution and allowed to dry. The patient was made to sit or lie down comfortably. The elbow was bent to $90^{\circ}$ with the pronated forearm so that there was the prominence of the lateral epicondyle. Agni karma was done over the tender point on and around the lateral epicondyle with a radius of $2 \mathrm{~cm}$ from a central point. $10 \mathrm{ml}$ of madhu was taken in a sterile dish. It was heated to $90^{\circ} \mathrm{C}$. The tip of borosil pipette was kept 
in this honey till the tip attained the temperature of honey. The honey was then sucked using this pipette and eight drops were poured on the predetermined site leaving a space of $5 \mathrm{~mm}$ in between. On cooling, it was carefully moped off using wet cotton. A mixture of equal quantity of madhu and ghrta was then applied.

Figure 1: Agnikarma using madhu

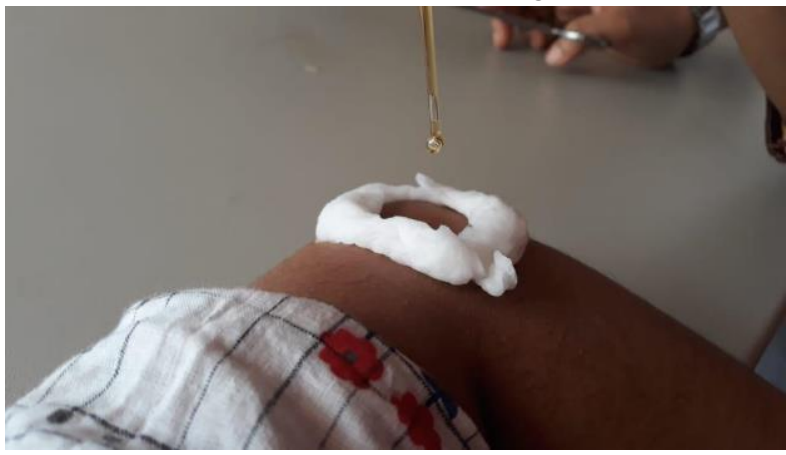

\section{Observation and analysis}

Table 1: Data obtained after statistical analysis

\begin{tabular}{|c|c|c|c|c|c|c|c|c|c|c|}
\hline \multirow[t]{2}{*}{ Variables } & \multicolumn{2}{|l|}{ Day1 } & \multicolumn{2}{|l|}{ Day8 } & \multicolumn{2}{|l|}{ Day15 } & \multicolumn{2}{|l|}{ Day22 } & \multicolumn{2}{|l|}{ Day29 } \\
\hline & $\begin{array}{l}\text { Mean } \\
\pm \text { Std. } \\
\text { Deviation }\end{array}$ & $\begin{array}{l}\mathbf{p} \\
\text { value }\end{array}$ & $\begin{array}{l}\text { Mean } \\
\pm \text { Std. } \\
\text { Deviation }\end{array}$ & p value & $\begin{array}{l}\text { Mean } \\
\pm \text { Std. } \\
\text { Deviation }\end{array}$ & p value & $\begin{array}{l}\text { Mean } \\
\pm \text { Std. } \\
\text { Deviation }\end{array}$ & p value & $\begin{array}{l}\text { Mean } \\
\pm \text { Std. } \\
\text { Deviation }\end{array}$ & p value \\
\hline $\begin{array}{l}\text { Cozen's } \\
\text { test }\end{array}$ & $7.25 \pm 0.93$ & $<0.001$ & $2.93 \pm 0.99$ & $<0.001$ & $1.62 \pm 0.80$ & $<0.001$ & $1.37 \pm 0.88$ & $<0.001$ & $1.18 \pm 0.98$ & $<0.001$ \\
\hline Mill's test & $7.0 \pm 1.2$ & $<0.001$ & $2.5 \pm 1.03$ & $<0.001$ & $1.18 \pm 0.83$ & $<0.001$ & $0.93 \pm 0.99$ & $<0.001$ & $1.0 \pm 0.96$ & $<0.001$ \\
\hline tenderness & $3.68 \pm 0.47$ & $<0.001$ & $1.62 \pm 0.5$ & $<0.001$ & $0.87 \pm 0.34$ & $<0.001$ & $0.56 \pm 0.51$ & $<0.001$ & $0.43 \pm 0.51$ & $<0.001$ \\
\hline $\begin{array}{l}\text { Active } \\
\text { wrist } \\
\text { flexion }\end{array}$ & $1.87 \pm 0.61$ & $<0.001$ & $0.68 \pm 0.60$ & $<0.001$ & $0.25 \pm 0.44$ & $<0.001$ & $0.12 \pm 0.34$ & $<0.001$ & $0.18 \pm 0.40$ & $<0.001$ \\
\hline $\begin{array}{l}\text { Active } \\
\text { wrist } \\
\text { extension }\end{array}$ & $1.81 \pm 0.65$ & $<0.001$ & $0.43 \pm 0.51$ & $<0.001$ & $0.31 \pm 0.47$ & $<0.001$ & $0.25 \pm 0.44$ & $<0.001$ & $0.12 \pm 0.34$ & $<0.001$ \\
\hline $\begin{array}{l}\text { Grip } \\
\text { strength }\end{array}$ & $5.93 \pm 0.68$ & $<0.001$ & $4.50 \pm 0.73$ & $<0.001$ & $3.68 \pm 0.60$ & $<0.001$ & $3.62 \pm 0.61$ & $<0.001$ & $3.25 \pm 0.44$ & $<0.001$ \\
\hline
\end{tabular}

Figure 2: Effect of Agnikarma

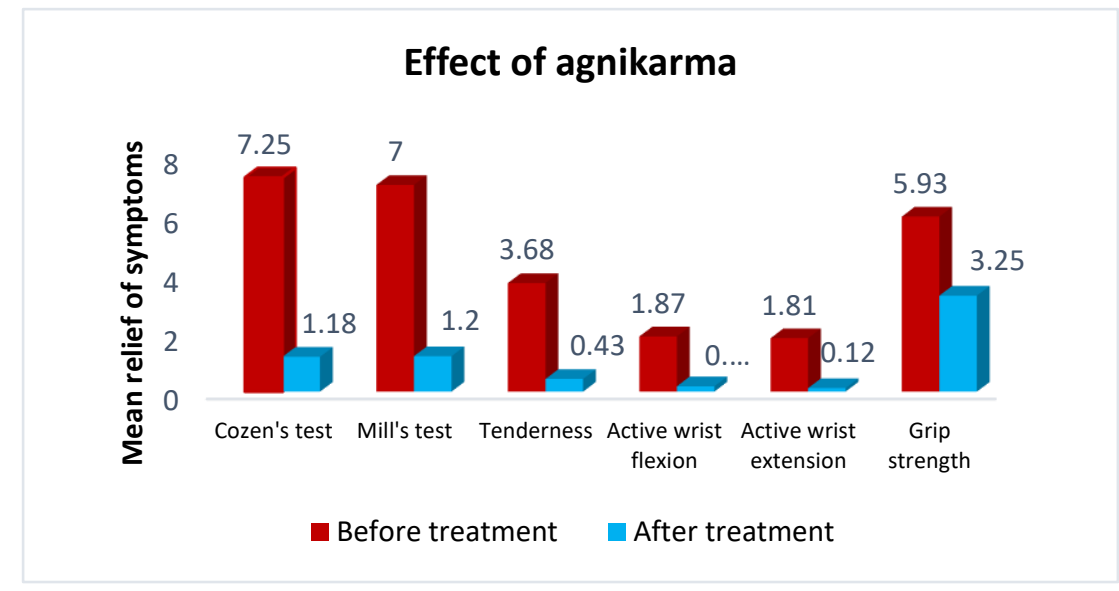




\section{DISCUSSION}

The khara pāka of medho dhātu results in the formation of snāyu. Vāta doșa acts on the medas and absorbs its snigdhāmśa resulting in the formation of tough structures called snāyu (tendon). ${ }^{14}$ In tennis elbow, due to nidāna factors vāta undergoes duști due to the exertion and repeated movements of the forearm and wrist and it undergoes takes sthāna samsraya in snāyu near kūrpara sandhi. As a result, kharatwa property again increases making it brittle and vulnerable to tears. The collagen loses its structure due to the constant force applied to the tendon for a prolonged period. This unstructured collagen indicates that the collagen no longer has the strength to perform its functions suggesting dhātu kșaya. This dhätu kșaya makes the tendon unable to bear the weight, resulting in reduced grip strength. Agnikarma is considered as a supreme anuśastra karma in Brhatraȳi. In snāyu gata vāta, snigdha agnikarma is indicated. ${ }^{15}$ The justification for the superiority of Agni karma may be taken in the context of the non-recurrence of disease in sādhya roga. ${ }^{12}$ Agnikarma is indicated in all vātaja and kaphaja diseases ${ }^{16}$ as the ușna guna of agni is opposite to that of sitta guna of vāta doșa and kapha dosa. According to an article by Petrofsky J S et al., the temperature of muscles, ligaments and tendons are below the core temperature of our body. The core temperature of our body is 37 degrees Celsius whereas on arms and legs the skin temperature is about 31 degrees Celsius. The temperature of the tissues like muscles and tendons which are situated below and deeper into the skin varies by the depth and the location. Usually deeper the tissue, the cooler the temperature they will be having. ${ }^{17}$ So on analyzing the concept of doșa there may be a predominance of $v \bar{a} t a$ and kapha doșa in the tendon as síta is a guna of vāta and kapha. Due to nidāna factors there occurs a vāta prakopa and an increase in rūkșa, khara and síta guna of the tendon. This may cause a decrease in the elasticity and strength of the tendon as well as the extensor muscles, resulting in tears and fibrotic changes. Also, the śìta guna of vāta and kapha causes stambana which may result in pain during movements. During the procedure of agnikarma, heat is transmitted in the form of conduction through the skin and tissues. So, by the process of snigdha agnikarma there occurs a transfer of usna guna of agni from madhu to the snāyu (tendon) which helps the tendon to overcome the síta guna of vāta and kapha.

An article by Nadler SF et al., states that on applying 40 degrees Celsius heat to the skin of the low back, the temperature of the muscle tissue at a depth of $38 \mathrm{~mm}$ gets increased by 2 degrees Celsius. ${ }^{18}$ According to an article by Okabe et al., the forearm has a thinner epidermis and so the dermal conductivity is more. From the above, it may be inferred that during the procedure of agnikarma on the lateral epicondyle, the tendon may get heated up with minimal heat loss. ${ }^{19}$ The heat generated in the tissue during agnikarma may stimulate the lateral spinothalamic tract which further may lead to stimulation of descending pain inhibitory fibres which release endogenous opioid peptides. These peptides bind with opioid receptors at substantia gelatinosa ronaldi which inhibits the release of substance P (presynaptic inhibition) and blockage of transmission of pain sensation. ${ }^{25}$ Thus it may be inferred that, during the process of agnikarma, along with uşna guna of Agni, the tìksna guna also helps for the deeper penetration of heat so that it reaches snāyu and together reduce the tenderness and pain through the process of vāta śamana.

According to Warren $\mathrm{C} G$ et al., at a higher temperature, there may be a relaxation of collagen in the connective tissue and thus it increases the flexibility of the tendon and enables it to sustain more force. ${ }^{20}$ The heat also relaxes the muscles, relieving the stiffness and increasing the range of movements. The ușna guña does vāta śamana and thus reduces the khara guna of the snāyu. This will result in increased elasticity of the tendon. In an article by A.G. Ravisankar et al., a temperature range of $40^{\circ} \mathrm{C}$ to $45^{\circ} \mathrm{C}$ may increase the extensibility of collagen tissue and thus reduce joint stiffness. The low melting temperature allows collagen molecules to melt and refold locally, which will provide elasticity and strength to the fibres. ${ }^{12}$ In the present study it was found that there is increased grip strength and range of movements of wrist in participants after agnikarma. 
This may be attributed to the fact that the ușna guna of Agni increases the elasticity of the tendon as evidenced by the above study.

In an article by A.G. Ravisankar et al., it was also discussed that after agnikarma due to a rise in temperature the cell activity may also increase along with the rate of cellular interactions. The heat applied on the site may increase the blood flow to the region by vasodilation, an increase in blood flow may help to increase the rate of healing as lack of proper healing of the torn tendon is also a pathology behind tennis elbow. ${ }^{12}$ According to the article by A.G. Ravisankar et al., the thermal behaviour of snigdha dravya was studied and it showed that the snigdha dravya has higher latent heat (heat retention capacity) with the average heat dissipation of $2^{\circ} \mathrm{C} / \mathrm{min}$. The article concluded that in snāyu gata vikāra, snigdha agnikarma may provide a better result than rūkșa agnikarma. ${ }^{12}$ In an article by Petrofsky $\mathrm{J}$ et al., it is stated that moist heat warms up the tissue faster than dry heat. ${ }^{21}$

Agnikarma using madhu was patient-friendly because the instrument used for the procedure was welcoming to the patient. Even the burning sensation felt during the procedure lasted only for 40 seconds to 50 seconds and so the participants showed no denial for the second sitting. Due to higher viscosity of madhu the tendency to flow away from the site was reduced and this tendency was even further reduced because of the decrease in temperature of droplets due to the heat transfer from the surface and the droplet gets colder after application. The drops of madhu did not flow away from the site and thus prevented the burning of the surrounding tissue and the temperature might have been transmitted to the specified area instead of spreading to the surroundings.

Heat energy (ușna guña) thus might have increased the tissue temperature, blood flow, metabolism and the extensibility of the connective tissue.

\section{CONCLUSION}

Agnikarma using madhu (honey) is found to be effective in tennis elbow. It showed $68.32 \%$ effectiveness in the management of tennis elbow.

\section{REFERENCES}

1. De Smedt T. et al. Lateral epicondylitis in tennis: update an aetiology, biomechanics, and treatment. $\mathrm{Br} \mathrm{J}$ Sports Med. 2007 Nov;41 (11):816-819.

2. Stasinopoulos D, Johnson MI. 'Lateral elbow tendinopathy'is the most appropriate diagnostic term for the condition commonly referred to as lateral epicondylitis. Medical hypotheses. 2006 Jan 1;67 (6):1400-2.

3. Nirschi RP, Ashman E. Tennis elbow tendinosis (epicondylitis). Instructional to course lectures, Feb 2004;53:587-98.

4. Vaquero-Picado A, Barco R, Antuña SA. Lateral epicondylitis of the elbow. EFORT open reviews. 2016 Nov;1 (11):391-7.

5. Ahmad $\mathrm{Z}$ et al. Lateral epicondylitis: a review of pathology and management. The bone \& joint journal. 2013 Sep;95 (9):1158-64.

6. Das S.A manual on clinical surgery. 10th rev. ed. Kolkata: Dr S. Das; 2013. 230p.

7. Hamilton PG. The prevalence of humeral epicondylitis: a survey in general practice. JR Coll Gen Pract. 1986, Oct1;36 (291):464-5.

8. Flatt A.E. Tennis elbow. Baylor University Medical Center Proceedings. 2008, Oct 1; 21 (4): p 400-402.

9. Deep V C et al. Role of agnikarma in tennis elbow. International Journal of Medical and Health Research. April 2017, 3 (4): 53-55.

10. Murthy Srikantha K.R., ed. Suśruta Samita of Suśruta. Cikitsāsthāna (translation. English) reprint edition. Varanasi: Chaukhamba orientalia;2017: p57. 4/8.

11. Murthy Srikantha K.R., ed. Suśruta Samita of Suśruta. Sutrasthāna; (translation. English) reprint edition. Varanasi: Chaukhamba orientalia;2017: p 70.12/4.

12. Ravishankar A.G. et al. A scientific and analytical approach on 'snigdha agnikarma'. Int. J. Res.Ayurveda Pharm.Dec 2013, 4 (6):851-853.

13. Krishnanand C.A. A comparative study of agnikarma using kşaudra and pancadhātu śalāka in gridhrasi WSR to sciatica. (MS dissertation) Dept. of Śalyatantra Alva's Ayurveda medical college; 2009 -10.

14. Patil C.V., ed. Suśruta Samhita of Suśruta. Śarìrasthāna; (English translation and Dalhana commentary). New Delhi: Chaukhamba; 2018: p161.4/30.

15. Patil C.V., ed. Suśruta Samhita of Suśruta. Sutrasthāna; (English translation and Dalhana 
commentary). New Delhi: Chaukhamba; 2018: p147. $12 / 4$.

16. Patil C.V., ed. Suśruta Samhita of Suśruta. Sutrasthāna; (English translation and Dalhana commentary). New Delhi: Chaukhamba; 2018: p150. $12 / 10$.

17. Petrofsky JS, Laymon M, Lee H. Effect of heat and cold on tendon flexibility and force to flex the human knee. Medical science monitor: international medical journal of experimental and clinical research. 2013; 19:661.

18. Nadler SF, Weingand K, Kruse RJ. The physiologic basis and clinical applications of cryotherapy and thermotherapy for the pain practitioner. Pain physician. 2004 Jul 1;7 (3):395-400.

19. Okabe $\mathrm{T}$ et al. Non-invasive measurement of effective thermal conductivity of human skin with a guardheated thermistor probe. International Journal of Heat and Mass Transfer. 2018 Nov 1; 126:625-35.

20. Warren CG, Lehmann JF, Koblanski JN. Heat and stretch procedures: an evaluation using rat tail tendon. Archives of physical medicine and rehabilitation. 1976 Mar 1;57 (3):122-6.

21. Petrofsky $\mathbf{J}$ et al., Moist heat or dry heat for delayed onset muscle soreness. Journal of clinical medicine research. 2013 Dec;5 (6):416.

\section{Source of Support: Nil Conflict of Interest: None Declared}

How to cite this URL: Sreelatha $\mathrm{K}$ et al: Agnikarma Using Honey In Tennis Elbow. International Ayurvedic Medical Journal \{online\} 2021 \{cited November 2021\} Available from: HYPERLINK

http://www.iamj.in/posts/images/upload/2659_2664.pdf 